\title{
The Effect of Converting Workshop System into Production Line System on Production Lead-time and Raw Materials' Consumption
}

\author{
Samer Dakak ${ }^{1}$, Mhd Yaman Alkhen ${ }^{2}$ \\ ${ }^{1}$ Higher Institute for Applied Sciences and Technology (HIAST), Damascus, Syria \\ ${ }^{2}$ Higher Institute of Business Administration (HIBA), Damascus, Syria \\ ${ }^{1}$ samer.dakak@hiast.edu.sy, 2yamanyk9@gmail.com
}

\begin{abstract}
This paper aims to analyze the impact of converting production workshop system into production line system on production lead-time and raw material consumption. We apply a case study approach on Secured Food Company specialized in chocolate biscuits. The average of raw materials consumption and requested commands lead times were compared between two years: 2012 when the adopted production system was based on workshop system and 2020 when the production system was converted to production line system. We find that this shift has resulted in a large decline in production lead-time but in only a slight decrease in raw materials consumption. Hence, we recommend adopting production line system if there is a sufficient demand. Otherwise, production stations must be placed in a $U$ shape to reduce distances and lead times.
\end{abstract}

Keywords: Production workshop system, production line system, production lead-time, raw materials consumption. 


\section{Introduction}

Production is the basic function in companies, because it is responsible for satisfying customers' requirements and needs in terms of products or services, aiming at realizing the maximal profits, in order to insure the company's survival and development. Production process is achieved through a set of inputs' transformations leading to required outputs and products.

To optimize production, its process should be controlled through operations management that collaborate with other company's functions to assure the right quantity of products with the minimal costs and the best quality, in addition to realizing the layout flexibility to meet demand variations. The final objective is to minimize costs and maximize profits (Blokayk, 2020).

Several production systems could be adopted according to the characteristics of companies, products and demands. Some companies follow the workshop system, which is characterized by gathering the same specialized machines in one place (functional Islands). Commands pass from one section to another as needed. Other companies follow the production line system, which is recognized by ordering machines according to the product's sequenced operations. Raw materials are fed in the line upstream, to exit as final products in the line downstream. When changes in product are needed, machines are reordered according to the new product's sequenced operations (David and Hendrik, 2020)

The two systems, workshop and production line, are fundamentally different in terms of worker's qualifications' requirements, flexibility degrees and production lead times. It is interesting to find out the impact of conversion from workshop production systems into production line systems, or vice versa, on production-led time and raw materials consumption to improve their production process and achieve their strategic objectives (Mario, 2020). Hence, this article investigates the impact of converting production workshop system into production line system on production lead-time and raw material consumption in a Food Company specialized in chocolate biscuits production.

\section{Value and Waste Elimination}

Continuous improvement is the base of any process to maintain value-added activities, all activities without any value perceived by customers should be eliminated. The value could be obtained through an activity, process or operation that delivers a product meeting the customer requirement (Nilsson, 2018). The key drivers to customer value or end-user value of a product or service can be further identified using the total value metric (Fig.. 1) as below. (Mostafaa and Dumrak, 2015). 


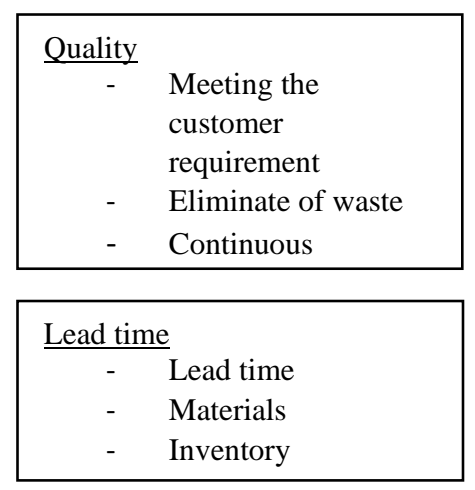

$$
\begin{aligned}
\hline \text { Service } & \text { Level } \\
\hline- & \text { Customer and product support } \\
- & \text { Product service } \\
- & \text { Satisfying customer demands. }
\end{aligned}
$$

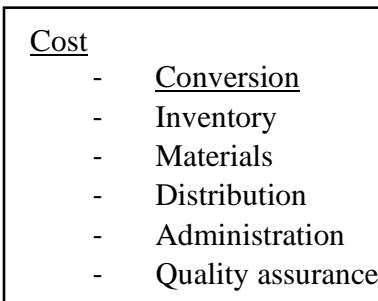

Source: Mostafaa \& Dumrak (2015)

Fig. 1: Total Value Metric

\section{Waste Elimination in Manufacturing}

Increasing profitability could be achieved through waste elimination. Some processes add value to the production of a good or service, others add "waste". Before eliminating waste, this waste should be localized and analyzed. Waste types faced in manufacturing are almost the same ones in all sectors. (Gladysz, Buczaki, and Haskins, 2020).

There are several strategies to reduce or eliminate waste according to the waste type, each strategy requires certain resources. Choosing the wrong resource or directing the appropriate resource to the wrong destination could lead to a waste creation. So, time is consumed, costs are accumulated. The final result is that customers are not satisfied.

Minimizing operating costs could be obtained by different ways like space optimization, operators lay-off and plant reorganization. Selecting the right way to minimize operating costs depend on several factors, such as customers, raw materials, infrastructures and government legislation (Norzaimi Che Ani, Kamaruddin, and Abdul Azid, 2019)

Types of wastes in manufacturing industry are variable:

1. Waiting time: the waste of waiting take place when goods are in a stop state. Distances between work stations are too excessive. Production runs are too long because material flow is slow.

2. Transporting: handling, movement and transport between processes create costs and could cause damage. Deterioration of product quality may occur.

3. Overproduction: when starting manufacturing of an item before it is really required. The results are high storage costs and excessive lead times.

4. Useless Inventory: overproduction and waiting could create this kind of unnecessary inventory. All types of negative results of excessive inventory could 
appear.

5. Defects: Defects create a great part of unnecessary total manufacturing costs. Reducing defects could be obtained through Continuous Process Improvement (CPI) and employee involvement.

6. Inappropriate processing: when organizations use high precision and too expensive equipment instead of simple tools that can be enough to get the same requirements.

7. Useless Motion: ergonomics must be carefully applied to analyze bending, stretching, walking, lifting, and reaching, in order to save unnecessary efforts.

\section{Strategies for Minimizing or Eliminating Wastes}

Waste minimization includes all practices reducing all types of waste. In manufacturing, waste minimization may include replacement of equipment, changes of material, modifications of product design, changes of inventory management style, changes of operational \& maintenance procedure. (Chetan, Mnish, Dakhore, 2014).

By adopting various ways of waste management, all manufacturing companies, such as metal, plastic and food industry have an objective to maximize their production by reducing waste to take control on their cost. Reducing and eliminating waste can be achieved by applying waste management techniques. (Kučerová, Míkva, Sablik, and Gejguš ,2015).

Because of its high cost, the first type of waste that manufacturers attempt to minimize is process wastes.(Manzouri, Ab-Rahman, Rosmawati, Zain, 2014).

Strategies of waste reduction or minimization are:

- Process monitoring and quality control: establishing several inspection and monitoring point's inspection can ensure that products are conform and accepted.

- $\quad$ Reusing the scrap material: to reduce waste of materials.

- Exchanging waste: This is another method for reducing waste. By making the waste resulting from a process, becomes a resource for another process.

- Supply chain: deliveries of raw materials should be used in the manufacturing process, at the point of assembly with fewer packages and coverings.

- Resources Utilization: attention should be paid on the proper utilization of raw materials.

\section{Literature Review}

Studies interested in changing production systems are scares. Production lead-time has been analyzed to shorten time and decrease costs (Rosenblatt, 2007). For example, Hu, Williams, Mason, Found (2016) investigated problems associated with changing production systems in Chinese SME's. They analyze practical 
problems related to consultancy-involved LPS implementation in Chinese SMEs and appropriate way to deal with them. They conclude that implantation of new production systems, such as Lean Production System (LPS) into SMEs, consultants and SME clients need to adopt a more positive and practical approach.

Uhl (2016), focused on the manufacturing spaces between the fifteenth and the twentieth century. He noticed that workshops, manufactories and factories are determined by the technology and architecture of their time. Also, they conclude that workshops, manufactories and factories are characterized by the social relationships.

Taboada, Garcia, Gilles, Pozo, Yucraa, Rojasa (2017), focused on how farmers in four Andean ecosystems faced risks and how they adapted production systems to changing risks over the past 20 years, using participatory research methods and cost benefit analysis. On the other hand, Lopatowska (2017) outlined factors determining selection of planning and control system. She compares the characteristics of selected systems of production planning and control. She argues that these characteristics serve as a basis for determining key market factors related to production planning and control functions, which in turn determine the choice of an appropriate system.

In a pilot project conducted by Chaudhry \& Woodruff (2013) in one of the largest fan factory producers in Pakistan, they investigate the impact of moving production from batch to assembly line production. First, The factory managers were convinced that assembly lines means higher productivity. However, moving to assembly lines, even within workshops, necessitated several changes in workers' behavior and practice, because the factory consists of a series of separated rooms. The shift to assembly line production gives obvious positive results in terms of time saving and materials consumption, in addition to workers' motivation.

Mars, the chocolate manufacturer, has fixed a goal of zero-waste by 2015. Since establishing its waste target in 2007, Mars has conducted an overall reduction of about 4,500 metric tons of chocolate waste each year. In order to achieve the goal of developing a more lean and efficient manufacturing operation in North America and further afield, first, Mars focused on three main points: recycling programs for multiple waste streams, getting partnerships with disposal vendors and local farm re-use programs and realizing efficient operating processes. Second, Mars plans to have partnership with warehouses and regional distribution centers to adopt similar waste reduction policies.

To sum up, little attention was given in previous literature towards converting workshops into production lines system (or vice versa) as a strategy to reduce manufacturing waste, with all the consequences associated with this conversion. The Pakistani producer of fans is the closest case to this article's approach of decreasing manufacturing waste through converting production systems. 


\section{Converting Production Systems}

Production systems could be classified according to different criteria, such as on the basis of relations with customers (stocking production or on-demand production), or production varieties and production order quantities (production line, workshop, process and project), or the production continuity (continuous, discrete).

Every production system has different advantages, disadvantages, mechanisms and management styles. However, all of them aims to achieve conflicting production management objectives which are shortening lead time, improving quality, contracting cost and increasing flexibility. (Mengi, 2015).

Some companies aimed at improving performance ratios of production management. To this end, they try to decrease raw material costs by adopting some policies such as surplus materials promotion and transforming waste material in new required ones such as yogurt serum, rice waste, corn waste and to produce glycerin and amine acids (Koller, 2010). Other companies tried to connect innovative thinking to industrial production problems in order to assure production continuity, improve specifications, decrease cost and time.

Some models have been developed to solve factories waste time, particularly clothes fabrication, by ordering machines differently and realizing optimal equilibrium of production line. Efficiency and other production ratios have been evaluated inside the production line. The results were decreasing operating time and decreasing number of production line worker, leading to general productivity improvement (Mustafa and Cheng, 2017).

Few experiences were oriented toward changing the production system itself through converting workshop system into production line or into fixed process system. The scarcity of these experiences may be due to special specifications of each system and how deep it fits to the nature of products and available machines (Virmani, Saha, Sahai, 2017).

Converting the production processes influences machines ordering, workers number, production process design and production management directions. It requires a thorough and complete study in terms of costs, waste, quantities, number of workers ... etc. A compromise should be realized between the flexibly of having multi-products (by resetting up the production line) and increasing the number of workers (in workshops)

Concerning converting process, production management adopt the following steps: eliminate workshop organization, insure a large surface to set the production line, relocate machines to the new place, ordering machines in a correct sequence, naming workers, training workers, elaborating production plan, then taking-off production (Garbie, 2011).

\section{The case study: Secured Food Company Conversion into a Production Line}


Secured Food Company, specialized in Wafer biscuits, has been founded in Damascus southern suburb in 1998. Its first location was a small hired store. After procuring new machinery, the location became a large campus in 2020. Choosing this company has been based on its representation of a large local extended sector, and the will of its top management to improve its production performance by analyzing its production system.

Secured Food production was following workshop system since its foundation. The company was composed of preparation section, oven, filling section, first cooling section, cutting section, coating section, decorating section, second cooling section, packing section.

The top management has noticed a large waste in raw materials' consumption and a delay in delivery dates. Precise data has been collected in 2012 as follows

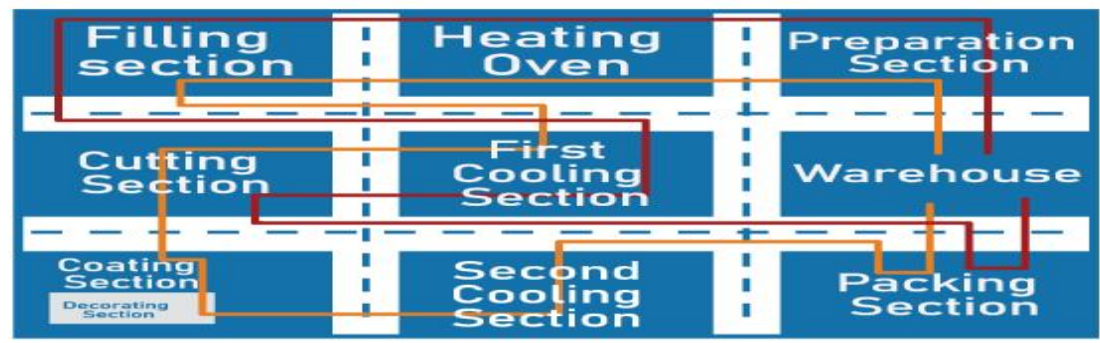

Source: Authors based on the company documents

Fig. 2: Workflow of the Company's Workshop Production System

Table 1: Volumes of raw material, production and commands lead times during 2012

\begin{tabular}{|r|r|r|r|r|}
\hline \multicolumn{1}{|l|}{ Month } & Raw materials & $\begin{array}{r}\text { Production } \\
\text { (tons) }\end{array}$ & $\begin{array}{r}\text { Waste in raw } \\
\text { materials (tons) }\end{array}$ & $\begin{array}{r}\text { Command lead } \\
\text { time (days) }\end{array}$ \\
\hline 1 & 5 & 4.9 & 0.1 & 2 \\
\hline 2 & 7 & 6.8 & 0.2 & 2.2 \\
\hline 3 & 6 & 5.9 & 0.1 & 2.1 \\
\hline 4 & 5.5 & 5.3 & 0.2 & 2 \\
\hline 5 & 4 & 3.9 & 0.1 & 2.5 \\
\hline 6 & 5 & 5 & 0 & 2.6 \\
\hline 7 & 3 & 2.9 & 0.1 & 2.3 \\
\hline 8 & 4 & 3.9 & 0.1 & 2.4 \\
\hline 9 & 5 & 5 & 0 & 2.3 \\
\hline 10 & 6 & 5.8 & 0.2 & 2 \\
\hline 11 & 7 & 7 & 0 & 1.9 \\
\hline 12 & 8 & 7.8 & 0.2 & 2.4 \\
\hline Total & 65.5 & 64.2 & 1.3 & 26.7 \\
\hline Average & 5.4583 & 5.35 & 0.1083 & 2.225 \\
\hline
\end{tabular}

Source: Authors based on company documents

The above mentioned data show that there was an average of raw material waste equal to $5.4583-5.35=0.1083$ tons $/$ month 
Several reasons have led to the move toward a larger location suitable to the increasing production due to geographical extending sales, adopting an export policy to some Arab neighboring countries. The new location also fits a large entrance to receive raw materials and to quality requirements.

Capitalizing on location replacement in 2020, the company's top management converted its production workshop system into production line system. Converting process passed by several steps such as infrastructure preparations (electricity, water, sanitary extensions, etc.) as well as modifying machines to be connected as a production line, and integrating programmable software to achieve flexibility in products variety. Purchasing machines to inject materials (Wafer Paste, cream, chocolate ...) into heating oven containers avoiding its movement risk. On the other hand, larger mixers machines have been purchased and a decorating spray machines were developed to assure spraying a standard quantity of decorating elements on biscuits. Finally, a cooler machine has been procured to cool finished products. Then, machines have been ordered and connected according to the production sequences, before training workers on the new production system.

\section{The New Production System}

Sections such as filling section, preparation section, packing section, coating section have been cancelled. Production line system has been established in two lines with the common heater oven. Fig. 2 describes the workflow according to the production line system.

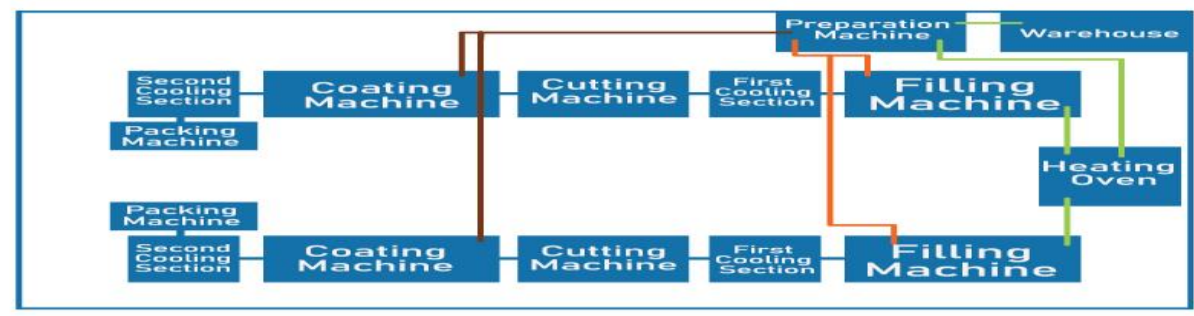

Source: Authors based on company documents

Fig. 3: Workflow of the Company Production Line System

Precise data has been collected in 2020 concerning raw materials consumption, and a delay in delivery dates. Table 2 shows that the average of consumed raw materials is 9.79 tons, which is more than the average production volume of 9.75 tons. It means that the waste is just $9.7916-9.7508=0.0408$ ton and the command lead time average is 1.675 days.

Table 2: Volumes of raw material, production and commands lead times during 2020

\begin{tabular}{|r|r|r|r|r|}
\hline Month & $\begin{array}{r}\text { Raw materials } \\
\text { (tons) }\end{array}$ & $\begin{array}{r}\text { Production } \\
\text { (tons) }\end{array}$ & $\begin{array}{r}\text { Waste in raw } \\
\text { materials (tons) }\end{array}$ & $\begin{array}{r}\text { Command lead } \\
\text { time (days) }\end{array}$ \\
\hline
\end{tabular}




\begin{tabular}{|r|r|r|r|r|}
\hline 1 & 9 & 8.99 & 0.01 & 1.5 \\
\hline 2 & 8 & 7.97 & 0.03 & 1.7 \\
\hline 3 & 10 & 10 & 0 & 1.4 \\
\hline 4 & 9 & 8.98 & 0.02 & 1.5 \\
\hline 5 & 11 & 10.97 & 0.03 & 1.8 \\
\hline 6 & 10 & 9.96 & 0.04 & 2 \\
\hline 7 & 10.5 & 10.2 & 0.3 & 1.9 \\
\hline 8 & 8 & 7.99 & 0.01 & 1.7 \\
\hline 9 & 10 & 9.99 & 0.01 & 1.5 \\
\hline 10 & 9 & 8.97 & 0.03 & 1.8 \\
\hline 11 & 12 & 11.99 & 0.01 & 1.4 \\
\hline 12 & 11 & 11 & 0 & 1.9 \\
\hline Total & 117.5 & 117.01 & 0.49 & 20.1 \\
\hline Average & 9.7916 & 9.7508 & 0.0408 & 1.675 \\
\hline
\end{tabular}

Source: author based on company documents

\section{Research Methodology}

To compare results in the two systems (production line and workshop), Paired sample t-test has been adopted using Statistical Package for the Social Sciences (SPSS) V27. We compare averages in raw material consumption waste and in command lead-times between both methods. This test examines if there is a significant difference between the averages between both samples.

\section{Comparing waste in raw material consumption}

To examine if there is a significant difference between waste averages in both systems, we compute the p-value from the paired sample t-test. We find that the $\mathrm{p}$ value is 0.069 , which is greater than 0.05 and suggests that there is insignificant difference in waste average between both systems. The results in Table 3 shows that the waste in production line is slightly lower than the waste in the workshop system.

Table 3: Comparison of raw materials consumption between workshop and production line.

\begin{tabular}{|c|c|c|c|c|c|c|c|c|c|}
\hline \multicolumn{10}{|c|}{ Paired Samples Test } \\
\hline & & \multicolumn{5}{|c|}{ Paired Differences } & \multirow[t]{3}{*}{$\mathbf{t}$} & \multirow[t]{3}{*}{ df } & \\
\hline & & \multirow[t]{2}{*}{ Mean } & \multirow[t]{2}{*}{$\begin{array}{l}\text { Std } \\
\text { Deviation }\end{array}$} & \multirow[t]{2}{*}{$\begin{array}{l}\text { Std } \\
\text { Error } \\
\text { Mean }\end{array}$} & \multicolumn{2}{|c|}{$\begin{array}{l}95 \% \\
\text { Confidence } \\
\text { Interval of the } \\
\text { Difference }\end{array}$} & & & \\
\hline & & & & & Lower & Upper & & & \\
\hline $\begin{array}{l}\text { Pai } \\
\text { r1 }\end{array}$ & $\begin{array}{l}\text { Waste } \\
\text { (workshop) } \\
\text {-Waste } \\
\text { (Prod Line) }\end{array}$ & 0.0675 & 0.11616 & 0.03353 & $\begin{array}{l}- \\
0.0063\end{array}$ & 0.1413 & 2.013 & 11 & 0.069 \\
\hline
\end{tabular}

Source: authors based on SPSS output

\section{Comparing lead-time production}


Table 4 shows the results from applying paired sample t-test to compare leadtime production between both systems. To analyze if there is a significant difference between lead-times averages in the two systems, we compare the computed significance level of 0.000 with 0.05 . (0.05 is higher than 0.000$)$, and we reject the null hypothesis of no difference between the lead-time production in both systems and conclude that there is a significant difference in command lead-time average in both systems. As data shows, the lead-time average in workshop system is 2.225 days, while it is only 1.675 days in production line.

\section{Conclusions}

The conversion process of workshop production system into production line system has succeeded in solving commands lead-time waste by saving an average of 0.55 days. However, concerning raw material consuming, the conversion process has slightly decreased material waste by 0.0675 tons per month, though insignificant.

Table 4: Comparison of lead-time production between workshop and production line.

\begin{tabular}{|c|c|c|c|c|c|c|c|c|c|}
\hline \multicolumn{10}{|c|}{ Paired Samples Test } \\
\hline & & \multicolumn{5}{|c|}{ Paired Differences } & \multirow[t]{3}{*}{$\mathbf{t}$} & \multirow[t]{3}{*}{ df } & \multirow{3}{*}{$\begin{array}{l}\text { Sig. (2- } \\
\text { tailed) }\end{array}$} \\
\hline & & \multirow[t]{2}{*}{ Mean } & \multirow[t]{2}{*}{$\begin{array}{l}\text { Std } \\
\text { Deviatio } \\
n\end{array}$} & \multirow[t]{2}{*}{$\begin{array}{l}\text { Std } \\
\text { Error } \\
\text { Mean }\end{array}$} & \multicolumn{2}{|c|}{$\begin{array}{l}95 \% \text { Confidence } \\
\text { Interval of the } \\
\text { Difference }\end{array}$} & & & \\
\hline & & & & & Lower & Upper & & & \\
\hline $\begin{array}{l}\text { Pair } \\
1\end{array}$ & $\begin{array}{l}\text { Lead-time } \\
\text { (workshop) } \\
\text { - Lead-time } \\
\text { (Prod Line) }\end{array}$ & 0.55000 & 0.16237 & 0.04687 & $\begin{array}{l}0.4468 \\
4\end{array}$ & 0.65316 & 11.734 & 11 & 0.000 \\
\hline
\end{tabular}

Source: authors based on SPSS output

We recommend replacing workshop production system by a production line system in this company and if technical specifications allow this conversion because of the opportunity to shorten production lead-time and decrease raw material consuming. However, if technical specifications do not allow the conversion, workshop sections should be ordered in $U$ shape, in order to lower distances and movement times between sections.

We also suggest that more attention should be paid to prevent accelerating conversion process. Infrastructure elements should be customized to specificities of production line system after conducting a feasibility study of the conversion process. 


\section{References}

Blokdyk, G. (2020). Operations Management A Complete Guide, 5STARCooks. 197-199

Chetan S., Manish. S. \& Dakhore. M (2014). Reducing Waste in Production by Lean Thinking, A case study. International Journal of Engineering Research \& Technology (IJERT), 3(6), 381-386

David, G., \& Hendrik, R (2020). Operations Management for Business Excellence: Building Sustainable Supply Chains, 4th Edition, Routledge. Chapter : Process Design and Strategy: 105-115.

Fernadez. M (2020). Industrial Engineering - Operations Management. Editions Paperback. 222-250

Garbie, I.H (2011). Converting Traditional Production Systems to Focused Cells as a Requirement of Global Manufacturing. Journal of Service Science and Management, 4, 268-279

Gładysz, B., Buczacki. A and Haskins. C (2020). Lean Management Approach to Reduce Waste in HoReCa Food Services, Resources journal, 9(144), 1-20

Hu, Q, Williams, S. J., Mason, R. \& Found s P. (2016). The change of production systems through consultancy involved projects: a multiple case study in Chinese SMEs, The Management of Operations, 27(7-8), 550-562.

Koller, M., Atlic, A., Miranda de Sousa Dias, M., Reiterer, A., \& Braunegg, G. (2010). Microbial PHA Production from Waste Raw Materials. In T. I. Stein (Ed.), Plastics from Bacteria: Natural Functions and Applications, 14, 85-119. (Microbiology Monographs). Springer.

Kučerová M, Míkva M, Sablik J, Gejguš M (2015). Eliminating waste in the production process using tools and methods of industrial engineering. Production Engineering Archives, 9(4), 30-34

Lopatowska, J. (2013). Factors determining selection of planning and control system, Management Trends in Theory and Practice, ed. S. Hittmar, University of Zilina, Slovakia, EDIS, University Publishing House, University of Zilina, 32-34 
Manzouri M, Ab-Rahman M.N, Rosmawati C, Zain C.M (2014). Increasing Production and Eliminating Waste through Lean Tools and Techniques for Halal Food Companies. Sustainability journal, 6, 9179-9204

Mengi. O (2015). Creative Industries Through Changing Mode of Production: A Debate on Fashion Industry. Conference of Cultural and Creative Industries: Economic Development and Urban Regeneration, Tre University, Rome, Italy, Dec 4 -5.

Mostafaa. S \& Dumrakb. J (2015). Waste elimination for manufacturing sustainability. 2nd International Materials, Industrial, and Manufacturing Engineering Conference, Bali Indonesia, 11-16

Mustafa. K \& Cheng. K (2017). Improving Production Changeovers and the Optimization: A Simulation Based Virtual Process Approach and Its Application Perspectives, 27th International Conference on Flexible Automation and Intelligent Manufacturing, FAIM, June, Modena, Italy. 898-913

Nilsson. E (2018). Improving material flow and production layout using Value Stream Mapping. A case study in a manufacturing company. Jonkoping University - school of Engineering, 43.

Norzaimi. M., Ani C., Kamaruddin. S., Abdul Azid. I. (2019). Achieving wastefree manufacturing processes through an effective series link production system. Int. J. Management Concepts and Philosophy, 12(1), 1-18.

Rosenblatt, M. J., \& Lee, H. L. (1986). Economic production cycles with imperfect production processes. IIE transactions, 18(1), 48-55.

Taboada, C., Garcia,M., Gilles, J., Pozo, O., Yucraa, E, Rojasa, K (2017). Can warmer be better? Changing production systems in three Andean ecosystems in the face of environmental change. Journal of Arid Environments, 147. 1-11

Uhl, Karsten (2016). Work Spaces: From the Early-Modern Workshop to the Modern Factory, in: European History Online (EGO), published by the Leibniz Institute of European History (IEG), Mainz 2016-05-02.

Virmani N, Saha R, Sahai R (2017). Quantifying Key Factors Affecting Leagile Manufacturing System. World Academy of Science, Engineering and Technology International Journal of Information and Communication Engineering, 11(4), 0231030 . 